\title{
PENGARUH EKSTRAK GRAPTOPHYLLUM PICTUM TERHADAP PERTUMBUHAN CANDIDA ALBICANS PADA PLAT GIGI TIRUAN RESIN AKRILIK
}

\author{
Endang Wahyuningtyas
}

\author{
Bagian Prostodonsia Fakultas Kedokteran Gigi Universitas Gadjah Mada
}

\section{Key words: \\ Graptophyllum pictum extract, Candida albicans, Acrylic resin denture plate.}

\begin{abstract}
Graptophyllum pictum (Daun ungu) is one of the traditional plants in Indonesia. Graptophyllum pictum composition is flavonoid, Flavonoid has an antimicrobial effect. The purpose of this study is to find the effect of Graptophyllum pictum extract prevent the growth of Candida albicans on acrylic resin denture plate. The research was done plaque smear which Candida albicans adhered at the patient denture, then it was cultured and Candida albicans growth was cultivated. The research was done by using 40 samples. The samples were heat cured acrylic resin discs with $10 \mathrm{~mm}$ diameter. The research was used dilution method. The samples were divided into four groups.. Each group had been given Graptophyllum pictum extract with 5\%, 10\%, 20\% and $40 \%$ for 8 hours. The plates with Sabouraud agar were incubated at $37^{\circ} \mathrm{C}$ for 24 hours and then Candida albicans were counted. The data were analyzed by the One way variant analysis and t-test. The result showed there were significant differences among the amount of Candida albicans which grew in different concentration of Graptophyllum pictum extract $(\mathrm{p}<0.05)$. The conclusion was that Graptophyllum pictum extract had prevented the growth of Candida albicans on acrylic resin denture plate.
\end{abstract}

\section{Pendahuluan}

Resin akrilik merupakan bahan yang hingga saat ini masih digunakan di bidang Kedokteran Gigi. Lebih dari 95\% plat gigi tiruan dibuat dari bahan resin akrilik. ${ }^{1}$ Resin akrilik head cured memenuhi persyaratan sebagai bahan plat gigi tiruan karena tidak bersifat toksik, tidak mengiritasi jaringan, sifat fisik dan estetik baik, harga relatif murah, dapat direparasi, mudah cara manipulasi dan pembuatannya. $^{2}$ 
Gigi tiruan resin akrilik selalu berkontak dengan saliva, minuman dan makanan sehingga gigi tiruan merupakan tempat terbentuknya stain, karang gigi dan plak karena kurangnya pemeliharaan kebersihan gigi tiruan resin akrilik. $^{3}$ Pada pemakaian gigi tiruan resin akrilik, mukosa akan tertutup sehingga menghalangi pembersihan permukaan mukosa maupun permukaan gigi tiruan oleh lidah dan saliva sehingga terjadi akumulasi plak pada gigi tiruan. ${ }^{4}$ Plak pada gigi tiruan merupakan faktor penting yang dapat menyebabkan inflamasi pada mukosa palatal dan terjadinya denture stomatitis. ${ }^{5}$ Faktor yang menyebabkan denture stomatitis adalah Candida albicans, infeksi bakteri, alergi, faktor psikologsi, kurangnya kebersihan gigi tiruan, aliran saliva dan nutrisi ${ }^{6}$.

Mikroorganisme yang sering diketemukan dalam rongga mulut adalah Candida albicans sekitar $40 \%$ sebagai bagian normal flora mulut. ${ }^{7}$ Candida albicans dapat melakukan penetrasi pada resin akrilik dan tumbuh pada permukaan gigi tiruan sehingga dapat menginfeksi jaringan lunak. ${ }^{8}$ Candida albicans dapat melepaskan endoktoksin yang merusak mukosa mulut dan menyebabkan terjadinya denture stomatitis", Oleh karena itu desinfeksi gigi tiruan merupakan faktor penting yang harus dilakukan. ${ }^{9}$

Pembersihan gigi tiruan dapat dilakukan dengan cara mekanis dan kimiawi. Pembersihan secara mekanis dengan sikat gigi, pembersihan secara kimia dengan merendam gigi tiruan dalam larutan desinfektans, alkali peroksida, alkali hipoklorit dan enzim. ${ }^{10}$ Upaya untuk mengatasi kenaikan jumlah flora mulut akibat pemakaian gigi tiruan dilakukan dengan cara pembersihan gigi tiruan dengan merendamnya dalam larutan desinfektans untuk menghindari kontaminasi bakteri dan jamur. ${ }^{11}$

Sesuai dengan anjuran pemerintah untuk melaksanakan budidaya tanaman tradisional, maka sekarang banyak bahan-bahan dari tanaman obat yang dijadikan bahan desinfeksi tradisional. Graptophylum pictum atau daun ungu merupakan salah satu tanaman obat tradisional. Daun Graptophylum pictum mempunyai khasiat sebagai obat sembelit, peluruh kencing, pelancar haid, obat bisul dan obat wasir. Kandungan kimia Graptophylum pictum antara lain flavonoid, tanin, alkaloid, steroid, saponin, alkohol, kalsium oksalat. ${ }^{12}$. Flavonoid merupakan golongan terbesar senyawa fenol, fenol monosiklik sederhana, fenil propanoid dan kuinon fenolik. ${ }^{13}$ Senyawa fenol dapat mengikat protein. Sifat umum senyawa fenol adalah mampu menambah permeabilitas sel dan mengendapkan protein. ${ }^{14}$ Senyawa flavonoid dapat menghambat mikroorganisme karena kemampuannya membentuk seyawa kompleks dengan protein dan bersifat antivirus 15,16 Tanin dapat digunakan sebagai aplikasi lokal luka pada kerongkongan dan rongga mulut terutama stomatitis. Tanin mempunyai aksi fisiologis dalam penghambatan bakteri. ${ }^{17}$ Ekstrak daun ungu (Graptophylum pictum) dapat menghambat pertumbuhan Streptococcus mutans pada plat resin akrilik. Ekstrak daun ungu (Graptophylum pictum) $40 \%$ efektif menghambat pertumbuhan plak pada gigi tiruan lengkap resin akrilik. ${ }^{18,19}$

Berdasarkan latar belakang tersebut, maka dirumuskan permasalahan sebagai berikut.

Apakah ekstrak Graptophyllum pictum berpengaruh terhadap pertumbuhan Candida albicans pada plat gigi tiruan resin akrilik?

Tujuan penelitian ini adalah untuk mengetahui pengaruh ekstrak Graptophyllum pictum dalam menghambat pertumbuhan Candida albicans pada plat gigi tiruan resin akrilik.

\section{Bahan dan Metode}

Pembuatan ekstrak Graptophyllum pictum dilakukan di Pusat Penelitian Obat Tradisional Universitas Gadjah Mada. Sebanyak 100 gram daun Graptophyllum pictum tua, dikeringkan dan digiling kemudian diekstraksi menggunakan etanol 70\% selama 3 jam. Cairan ekstrak dipekatkan dengan alat Vacum Rotary Evaporator sehingga didapat ekstrak kering. Pembuatan larutan ekstrak Graptophyllum pictum 5\% yaitu 5 gram ekstrak Graptophyllum pictum ditambah akuades hingga $100 \mathrm{ml}$. Untuk 
pembuatan ekstrak Graptophyllum pictum 10\%, $20 \%$ dan 40\% dilakukan cara yang sama dengan berat ekstrak Graptophyllum pictum 10 gram, 20 gram dan 40 gram.

Pembuatan sampel resin akrilik yaitu diameter model malam $10 \mathrm{~mm}$ dan tebal $2 \mathrm{~mm}$, dilakukan penanaman model malam dalam cuvet, diisi dengan resin akrilik heat cured, digodog 1 jam, kemudian dipolis sampai halus.

Pada penelitian ini dilakukan usapan plak yang menempel pada fitting surface gigi tiruan lengkap rahang atas pasien. Dibuat kultur dari usapan dan dibiakkan Candida albicans. Penelitian ini dilakukan di Laboratorium fakultas Kedokteran Hewan Universitas Gadjah Mada. menggunakan metode dilusi. Empat puluh sampel resin akrilik direndam dalam 10 $\mathrm{ml}$ suspensi Candida albicans selama 24 jam pada suhu $37^{0} \mathrm{C}$.. Seluruh sampel dibagi dalam 4 kelompok, tiap kelompok terdiri dari 10 sampel. Tiap kelompok direndam dalam ekstrak Graptophyllum pictum dengan konsentrasi 5\%, 10\%, 20\% dan $40 \%$ selama 8 jam. Sebagai kontrol 1 sampel direndam dalam akuades. Sampel resin akrilik, masing-masing dikoccok dengan vortex mixer selama 1 menit dan dilakukan pengenceran seri sampai $10^{-3}$. Diambil 0,01 ml larutan uji dari pengenceran 10 -3 , kemudian diteteskan pada petri agar Sabouraud dan dieramkan dalam inkubator selama 48 jam pada suhu $37^{\circ}$ C. Dilakukan penghitungan jumlah koloni Candida albicans pada masing-masing konsentrasi ekstrak Graptophyllum pictum. Jumlah koloni Candida albicans yang diperoleh digunakan untuk menghitung angka jamur dengan rumus.

Angka jamur $=\underline{\text { Jumlah koloni jamur } \mathbf{x} \text { faktor pengenceran }}$

Volume yang dihitung

Angka jamur yang diperoleh dapat digunakan untuk mengetahui daya anti jamur pada masing-masing konsentrasi dengan menghitung KHM

KHM $=100 \%-\underline{\text { AJT } \times 100 \%}$

AJK

Keterangan:

AJT : Angka jamur pada konsentrasi tertentu dalam satuan CFU/ml

AJK : Angka jamur pada larutan kontrol dalam satuan $\mathrm{CFU} / \mathrm{ml}$
Untuk mengetahui mengetahui pengaruh ekstrak Graptophyllum pictum dalam menghambat pertumbuhan Candida albicans pada plat gigi tiruan resin akrilik dilakukan analisis varian satu jalur dilanjutkan dengan uji t.

\section{Hasil}

Hasil perhitungan rerata dan standar deviasi angka jamur Candida albicans setelah direndam dalam ekstrak Graptophyllum pictum 5\%, 10\%, 20\% dan 40\% dapat dilihat pada tabel 1.

Tabel 1 menunjukkan hasil rerata angka jamur Candida albicans tertinggi pada ekstrak Graptophyllum pictum 5\%, yaitu 165,5 x $10^{3}$ CFU/ml dan angka jamur Candida albicans terendah pada ekstrak Graptophyllum pictum $40 \%$, yaitu $1,1 \times 10^{3} \mathrm{CFU} / \mathrm{ml}$.

Tabel. Hasil dan Standar Deviasi angka Namur Candida albicans pada ekstrak Gratophyllum pictum dengan onsentrasi yang berbeda (x $\left.10{ }^{3} \mathrm{CFU} / \mathrm{ml}\right)$

\begin{tabular}{crrc}
\hline Kelompok & N & \multicolumn{1}{c}{ Rerata } & Standar Deviasi \\
\hline A1 & 10 & 165.5 & 2,461 \\
A2 & 10 & 125,5 & 2,321 \\
A3 & 10 & 52,8 & 1,033 \\
A4 & 10 & 1,1 & 0,568 \\
\hline
\end{tabular}

Keterangan:

A1 = Angka jamur pada ekstrak Graptophyllum pictum 5\%, A2 = Angka jamur pada ekstrak Graptophyllum pictum $10 \%$ A3 = Angka jamur pada ekstrak Graptophyllum pictum 20\% A4 = Angka jamur pada ekstrak Graptophyllum pictum 40\% Keterangan ini dipakai untuk tabel selanjutnya.

Hasil perhitungan analisis varians satu jalur untuk mengetahui pengaruh ekstrak Graptophyllum pictum 5\%, 10\%, 20\% dan 40\% terhadap pertumbuhan Candida albicans dapat dilihat pada tabel 2 .

Hasil perhitungan analisis varians satu jalur adalah: Ada perbedaan bermakna antara ekstrak Graptophyllum pictum dengan konsentrasi 5\%, 10\%, 20\% dan 40\% terhadap pertumbuhan Candida albicans $(\mathrm{p}<0,05)$. 
Tabel 2. Hasil perhitungan analisis varians satu jalur angka jamur Candida albicans pada ekstra Graptophyllum pictum 5\%, 10 \%, 20\% dan $40 \%$

\begin{tabular}{llllll}
\hline $\begin{array}{l}\text { Sumber } \\
\text { Variasi }\end{array}$ & JK & Db & RK & F & P \\
\hline Antar & 161905,4 & 3 & 53968,4 & 16821,3 & $0,000^{*}$ \\
kelompok & 75 & & 92 & 48 & \\
Total & 115,500 & 36 & 3,208 & & \\
& 162020,9 & 39 & & & \\
& 75 & & & \\
\hline
\end{tabular}

berma $(p<0,05)$

Untuk mengetahui perbedaan antar kelompok dilakukan uji t yang dapat dilihat pada tabel 3 .

Hasil perhitungan uji $\mathrm{t}$ hádala sebagai berikut.Terdapat perbedaan bermakna antara angka jamur pada ekstrak Graptophyllum pictum 5\% dan $10 \%$, 5\% dan $20 \%$, 5\% dan $40 \%, \quad 10 \%$ dan $20 \%$, $10 \%$ dan $40 \%$, 20\% dan $40 \%$, terhadap pertumbuhan Candida albicans $(\mathrm{p}<0,05)$.

Tabel 3. Hasil uji-t antar kelompok angka Namur pada ekstrak Graptophyllum pictum dengan konsentrasi yang berbeda

\begin{tabular}{clc}
\hline \multicolumn{1}{c}{ Sumber } & \multicolumn{1}{c}{ Uji t } & \multicolumn{1}{c}{$\mathrm{P}$} \\
\hline A1 - A2 & 37,391 & $0,000^{*}$ \\
A1 - A3 & 133,541 & $0,000^{*}$ \\
A1 - A4 & 205,858 & $0,000^{*}$ \\
A1 - A3 & 90,483 & $0,000^{*}$ \\
A1 - A4 & 164,611 & $0,000^{*}$ \\
A1 - A4 & 138,726 & $0,000^{*}$ \\
\hline eterangan $~^{*}$ = Ada perbedaan bermakna $(\mathrm{p}<0,05)$
\end{tabular}

\section{Pembahasan}

Hasil penelitian menunjukkan bahwa rerata angka jamur Candida albicans pada ekstrak Graptophyllum pictum 5\% mempunyai nilai tertinggi sebesar 165,5 x $10{ }^{3} \mathrm{CFU} / \mathrm{ml}$ dan angka jamur Candida albicans terendah pada ekstrak Graptophyllum pictum 40\%, yaitu 1,1 x $10^{3} \mathrm{CFU} / \mathrm{ml}$. Hasil ini disebabkan bahwa ekstrak Graptophyllum pictum mengandung flavonoid yang mempunyai daya anti jamur. Eksrak Graptophyllum pictum 40\% mengandung flavonoid lebih tinggi dari Eksrak Graptophyllum pictum 5\%, sehingga perumbuhan Candida albicans lebih banyak dihambat. Hasil ini sesuai dengan pendapat Pelczar dan Chan ${ }^{15}$ yang menyatakan bahwa semakin tinggi konsentrasi suatu zat anti mikroorganisme akan semakin cepat pula sel mikroorganisme mati atau terhambat pertumbuhannya. Tyler 17 menyatakan kemampuan menghambat dan merusak proses kehidupan jamur oleh bahan anti jamur disebabkan adanya sifat terapoetiknya.

Pengaruh ekstrak Graptophyllum pictum masing-masing konsentrasi terhadap pertumbuhan Candida albicans dapat dilihat pada hasil perhitungan Analisis varian satu jalur. Hasil penelitian menunjukkan ada perbedaan bermakna pada ekstrak Graptophyllum pictum dengan konsentrasi 5\%, 10\%, 20\% dan 40\% terhadap pertumbuhan Candida albicans ( $<<0,05)$. Hasil uji $\mathrm{t}$ menunjukkan ada perbedaan bermakna antar kelompok konsentrasi ekstrak Graptophyllum pictum terhadap pertumbuhan Candida albicans $(\mathrm{p}<0,05)$. Hasil ini menunjukkan adanya daya hambat yang berbeda terhadap pertumbuhan jamur Candida albicans dari senyawa flavonoid yang dikandung oleh ekstrak Graptophyllum pictum. Flavonoid bekerja dengan cara denaturasi protein sehingga meningkatkan permeabilitas membran sel. Denaturasi protein menyebabkan gangguan dalam pembentukan sel sehingga merubah komposisi komponen protein. Fungsi membran sel yang terganggu dapat mentebabkan meningkatnya permeabilitas sel, sehingga mengakibatkan kerusakan sel jamur. Kerusakan tersebut menyebabkan kematian sel jamur. Candida albicans Hasil penelitan ini sesuai dengan penelitian Jawetz ${ }^{14}$ Flavonoid merupakan senyawa fenol yang dapat menyebabkan denaturasi protein.dan berfungsi sebagai anti bakteri dan anti jamur. Menurut Pelczar dan Chan ${ }^{15}$ denaturasi protein dapat merusak sel secara pemanen dan tidak bisa diperbaiki lagi.

Perhitungan Kadar hambat minimal (KHM) dengan menggunakan angka jamur kontrol sebesar $340 \times 10^{3}$ dan angka jamur pada masing - masing konsentrasi diperoleh KHM pada ekstrak Graptophyllum pictum 5\% sebesar 51,32\%, konsentrasi $10 \%$ sebesar 63,08\%, konsentrasi $20 \%$ sebesar $84,47 \%$ dan konsentrasi 40\% sebesar 99,68\%. Hasil tersebut menunjukkan bahwa ekstrak Graptophyllum pictum $40 \%$ mempunyai daya hambat yang 
lebih besar terhadap pertumbuhan Candida albicans dibandingkan dengan ekstrak Graptophyllum pictum konsentrasi 20\%, 10\% dan 5\%. Menurut Washington ${ }^{20}$ Larutan bersifat fungisida jika KHM mencapai 99,9\% dan bersifat fungistatik jika KHM kurang dari 99,9\%.. Dengan demikian ekstrak Graptophyllum pictum 40\% mempunyai daya hambat paling tertinggi dan bersifat fungistatik terhadap pertumbuhan Candida albicans.

Berdasarkan hasil penelitian tentang pengaruh ekstrak Graptophyllum pictum terhadap pertumbuhan Candida albicans pada plat gigi tiruan resin akrilik maka dapat diambil kesimpulan : Ekstrak Graptophyllum pictum dapat menghambat pertumbuhan Candida albicans pada plat gigi tiruan resin akrilik. Ekstrak Graptophyllum pictum 40\% mempunyai daya anti jamur tertinggi terhadap pertumbuhan Candida albicans pada plat gigi tiruan resin akrilik

\section{Daftar Pustaka}

1. Phillips RW. Skinner's science of dental materials. $9^{\text {th }}$ ed. Philladelphia. WB Saunder Co. 1991, p. 199-204.

2. Combe EC. Notes on dental materials. $6^{\text {th }}$ ed. Edinburg Churchill Livingstone. 1992. p . 79120, 157-61.

3. Neil DJ and Walter JD. Buku pintar geligi tiruan sebagian lepasan (Partial Denture). $2^{\text {nd }}$ ed. EGC. Jakarta. 1995. h. 84-5.

4. Basker RM, Davenport JC, Tomlin HR. Prosthodontics treatment for edentulous patien. 1 st ed. London. The Macmillan Press. 1976. p.163-5.

5. Abelson DG. Denture plaque and denture cleanser, J. Prosthet. Dent. 1981. 42: 376-9.

6. Santarpia III RP. Pollock JJ. Renner RP. and Spehowics E.An invivo replica metode of the site specific detection of Candida albicans on denture surface in denture stomatitis patients. J.Prosthet. Dent. 1990; 63(4): 437-43.
7. Nikawa $\mathrm{H}$ and Iwanaga $\mathrm{H}$. Invitro evaluation of Candida albicans adherence to soft \ denture lining material. J. Prosthet. Dent 1992; 68 (5) : 804-08

8. Lambert JP. and Kolstad k. Effect of benzoid acid -detergent germicide on denture- $\backslash$ borne Candida albicans. J.Prosthet. Dent 1986; 55 (4): 669-700.

9. Tamamoto M. Hamada T. Miyake Y. and Suginaka H. Ability of enzymes to remove Candida. J. Prosthet. Dent 1985; 53 (2):214-5.

10. Nakamoto K. Tamamoto $M$. and Hamada T. Evaluation of denture cleanser with and without enzym against Candida albicans. J. Prosthet Dent 1991; 66: 430-3

11. Dills SS. Olshan AM. Goldner S and Brogdon S. Comparison of the antimicrobial capability of an abrasive paste and chemical soak denture cleanser. J.Prosthet.Dent 1988; 60: 467-70.

12. Thomas ANS. Tanaman obat tradisional II, Yogyakarta. Kanisius. 1992. h 9-10.

13. Markham KR. Cara mengidentifikasi flavonoid.. ITB Press Bandung.1988. h.27.

14. Jawetz EM. Review of medical microbiology. 16 th ed. San Fransico. Longo Medical Pub. 1986. p. 143-8. 297-9.

15. Pelczar MJ, Chan ECS. Dasar-dasar Mikrobiology (terj.) Jakarta. Penerbit Universitas Indonesia 1988. h. 456-8.

16. Robinson T. Kandungan organik tumbuhan. Ed.4. ITB Press Bandung. 1995. h. 157-62.

17. Tyler VE. Brady LR. Roberts JE. Pharmaconogsy 9 ed. Lea and Ferbiger Philladelphia, 1988. 6780.

18. Wahyuningtyas E and Indrastuti M. Pengaruh ekstrak Graptophyllum pictum terhadap pertumbuhan bakteri Streptococcus mutans pada resin akrilik Maj. Ked. Gigi (Dent J.)Edisi khusus Temu Ilmiah Nasional IV. 2005. h.298-301.

19. Wahyuningtyas E The Graptophyllum pictum extract effect on acrylic resin complete denture plaque growth. Maj. Ked. Gigi (Dent J.) 2005. h. 201-4.

20. Washington, JA, Succeptibility test, macrodilutions and microdilutions broth procedure San Fransisco, Longo, Medical Pub, 1985, p 972-7. 